\title{
Statistical analysis of breast cancer data in a 3 years period (2016-2018) in Republic of North Macedonia and the Eastern region
}

\author{
Jihe Zhu ${ }^{1}$, Blagica Arsovska², Kristina Kozovska ${ }^{\star, \dagger, 3}$ \\ ${ }^{1}$ Faculty of Medical Sciences, University Goce Delchev, Shtip, Republic of Macedonia \\ ${ }^{2}$ Faculty of Medical Sciences, University Goce Delchev, Shtip, Republic of Macedonia and Institute of Biology, Faculty of Natural \\ Sciences and Mathematics, Skopje, Republic of Macedonia \\ ${ }^{3}$ Faculty of Medical Sciences, University Goce Delchev, Shtip, Republic of Macedonia and Medicine Faculty, St. Cyril and Methodius \\ University of Skopje, Republic of Macedonia \\ DOI: https://doi.org/10.15520/ijmhs.v9i9.2698
}

Accepted 31 Aug 2019; Received 15 Aug 2019; Publish Online 19 Sep 2019

\author{
Reviewed By: Dr. \\ Daniel V. \\ Department: Medical
}

\begin{abstract}
Breast cancer is on the first place of malignant disease in women. By mortality it is 4 th most common and the incidence is constantly increasing in the world, in North Macedonia as well. Unfortunately, the exact number for cancer patients in North Macedonia is not known, but it is estimated that there are about 800 to 1000 patients per year. Stress is a serious risk factor and with most of the cancer patients in the anamnesis it is found that they were exposed to extreme stress. After the Bosnian war in the $90 \mathrm{~s}$, there was a sudden incidence of breast cancer. The rate of healing in the early A1 stadium is from 98 to $100 \%$. The problem in North Macedonia is that the screening it's not performed often, which causes the disease to be diagnosed in the later stages. Most common is adenocarcinoma. In North Macedonia of all malignant neoplasms in women, breast cancer is first in mortality. Breast cancer mostly affects women aged 55 to 64 years at the level of the North Macedonia and the Eastern region. Compared to previous years, every year the number of breast cancer patients is increasing, which means that the incidence of cancer is increasing. Work plans should be directed to: health education of the population, education of women for proper and regular breast self-examination, education for regular screening for both women and the general practitioners who should support and educate the population on regular screening exams, as well as programs designed to support women who are being treated for breast cancer.
\end{abstract}

Key words: breast cancer-oncology-analysis

\section{INTRODUCTION}

Breast cancer is on the first place of malignant disease in women. By mortality it is 4 th most common and the incidence is constantly increasing in the world, in North Macedonia as well. Unfortunately, the exact number for cancer patients in North Macedonia is not known, but it is estimated that there are about 800 to 1000 patients per year. The rough incidence of breast cancer in the European Union is 109.9 and the mortality rate of 38.4 cases per 100,000

\footnotetext{
* Corresponding author.

$\dagger$ Email: tongdatang-tcm@hotmail.com.
}

women per year. In 2015 the annual incidence of breast cancer in Europe (40 countries) was 88.4 / 100000 and mortality $24.3 / 100000$. The incidence is increasing due to regular mammography screening and aging of the population, postmenopausal hormone replacement therapy, irregular diet, obesity and alcohol and tobacco consumption. The incidence increases with age, with about one quarter of breast cancer occurring before age 50 and $<5 \%$ before 35 years of age. In most Western countries, the death rate has declined in recent years, especially in younger age groups, due to improved treatment and earlier detection. However, breast cancer is still the leading cause of death from malignant disease in European women. 


\section{Statistical analysis of breast cancer data in a 3 years period (2016-2018) in Republic of North Macedonia and the Eastern region

Stress is a serious risk factor and with most of the cancer patients in the anamnesis it is found that they were exposed to extreme stress. After the Bosnian war in the 90s, there was a sudden incidence of breast cancer. Older age is the most consistent and significant risk factor, as many populations show increasing incidence rates with increasing age. Other risk factors include personal history and family history of breast cancer, nulliparous or high age at first childbirth, early menarche and late menopause, before breast biopsy with hyperplasia or atypical hyperplasia, high density of breast tissue, exposure to low age radiation, alcohol consumption and use of postmenopausal hormone therapy. Various studies have shown that breastfeeding, physical activity and maintaining a healthy body weight are associated with a reduced risk of breast cancer.

Most patients with $\mathrm{T} 1$ or T2 breast cancer are presented with a painless or slightly sensitive breast mass, or have abnormal screening mammograms. Patients with more advanced tumors may have sensitive breasts, skin changes, bloody nipple discharge, or occasional changes in breast shape and size. Rarely, patients may be presented with axillary lymphadenopathy and even distant metastases. As stated previously, depending on the tumor size, method of detection, and pathologic factors associated with the primary tumor, $30 \%$ to $40 \%$ of clinically negative axillary women may have subclinical pathologically involved axillary nodes.

There are different types of breast cancer. They are generally divided into two groups, non-invasive (without invasion into adjacent tissues) and invasive (with potential to spread).

The rate of healing in the early A1 stadium is from 98 to $100 \%$. The problem in North Macedonia is that the screening it's not performed often, which causes the disease to be diagnosed in the later stages. Most common is adenocarcinoma. [[1-6]]

\section{MATERIAL AND METHODS}

The method used for the purpose of this thesis is retrospective analysis of data obtained from registered patients with breast cancer in the period 2016-2018 in North Macedonia and the Eastern region.

For the purposes of this paper, data was obtained from:

- State Statistical Office of the Republic of North Macedonia,

- Institute of Public Health of the Republic of North Macedonia and

- Center for Public Health - Public Health Institution municipality Stip at the level of the Eastern region.

The data are analyzed and processed in detail and statistically, tabular and graphically presented in the paper.

\section{RESULTS AND DISCUSSION}

From the data provided by the State Statistical Office, and analyzed and compared by the Borka Breast Cancer NGO from Skopje, for 2017 it can be conclude that breast cancer is the most common cause of death from malignant neoplasms in women in Macedonia.

In 2017, 217 women died of breast cancer, or 27/100,000. Most are women aged 55 to 59 years. In 2017, 218 new cases were registered, 4 of which were for men. 15 new cases in women under 40. Studies have shown that the Pelagonian region is the first in the country to have breast cancer deaths. Breast cancer compared to other malignant neoplasms is in the first place for 2017 with $27 / 100000$. After breast cancer the second is bronchial and lung cancer, third is ovarian cancer and then all the rest.

Analyzed by age, most reported deaths are of women aged 55-59 and as the age increases, the number of deceased women increases.

Men, although with a very low 1 percent to a high 99 percent of women they can be affected by breast cancer. This data is for 2017 by the State Statistical Office.

Gynecomastia is the most common malignant breast pathology in men. Men's breast cancer occurs at the end of the fifth and sixth decades of life, about nine years later on average than in women. Risk factors should include family predisposition, liver disease, occupational exposure to high temperatures, radiation trauma to the breast, hormone therapy with estrogen in prostate cancer, where it has not yet been proven whether or not it is a primary concern.

Data obtained from the Public Health Center refer to patients diagnosed with breast cancer at the Clinical Center in Stip for 2016, 2017, 2018. The patients were from different municipalities in the Eastern region. Analyzing the figures it can be conclude that in 201620 cases were diagnosed, in 2017 - 25 cases, and in the previous 2018 - 36 new cases of breast cancer. Comparing the three years, we can conclude that breast cancer has a tendency to grow in the Eastern region.

The analyzed data on Tables 1,2 and 3 is from data obtained from the Stip Public Health Center, which refers to the number of breast cancer patients for 2016, 2017 and 2018 and includes the exact number of patients divided by age groups.

Table 1. Number of cases for 2016 by age groups

\begin{tabular}{ll}
\hline Age groups & Number of patients \\
$28-29$ & 2 \\
$30-34$ & 0 \\
$35-44$ & 2 \\
$45-54$ & 5 \\
$55-64$ & 5 \\
$65-74$ & 6 \\
$>74$ & 3 \\
\hline
\end{tabular}


Table 2. Number of cases for 2017 by age groups

\begin{tabular}{ll}
\hline Age groups & Number of patients \\
$28-29$ & 2 \\
$30-34$ & 0 \\
$35-44$ & 10 \\
$45-54$ & 4 \\
$55-64$ & 2 \\
$65-74$ & 4 \\
$>74$ & 2 \\
\hline
\end{tabular}

\section{REFERENCES}

[1] Сузан.М.Лав; Рак на дојката; Култура, 2008

[2] Принципи и практика на радиолошката онкологија; Перез и Брејди; Табернакул, Скопје, 2011.

[3] Упатство за практикување на медицина заснована на докази при рак на дојка; Министерство за здравство на Република Македонија [www.zdravstvo.gov.mk].

[4] Medical News Today; Breast Cancer News; 2019 [www.medicalnewstoday.com]

[5] Balentine RJ; Breast cancer facts; 2019 [www.medicinenet.com]

Table 3. Number of cases for 2018 by age groups

\begin{tabular}{ll}
\hline Age groups & Number of patients \\
$28-29$ & 0 \\
$30-34$ & 1 \\
$35-44$ & 2 \\
$45-54$ & 8 \\
$55-64$ & 17 \\
$65-74$ & 7 \\
$>74$ & 4 \\
\hline
\end{tabular}

[6] Македонски портал за ракот; Канцер (рак); 2017 [www.rak.mk].

Analyzing the figures for 2016, 2017 and 2018 obtained from the Center for Public Health - Stip we can conclude that most of the cases diagnosed with breast cancer are in the age of 55 to 64 years. These figures are presented in the following Table 4 .

Table 4. Number of patients in the period from 2016 to 2018 according to age groups

\begin{tabular}{lc}
\hline Age groups & Number of patients \\
$28-29$ & 4 \\
$30-34$ & 1 \\
$35-44$ & 14 \\
$45-54$ & 17 \\
$55-64$ & 24 \\
$65-74$ & 17 \\
$>74$ & 9 \\
\hline
\end{tabular}

\section{AUTHOR BIOGRAPHY}

Jihe Zhu Faculty of Medical Sciences, University Goce Delchev, Shtip, Republic of Macedonia

Blagica Arsovska Faculty of Medical Sciences, University Goce Delchev, Shtip, Republic of Macedonia and Institute of Biology, Faculty of Natural Sciences and Mathematics, Skopje, Republic of Macedonia

Kristina Kozovska Faculty of Medical Sciences, University Goce Delchev, Shtip, Republic of Macedonia and Medicine Faculty, St. Cyril and Methodius University of Skopje, Republic of Macedonia

In North Macedonia of all malignant neoplasms in women, breast cancer is first in mortality. Breast cancer mostly affects women aged 55 to 64 years at the level of the North Macedonia and the Eastern region. Compared to previous years, every year the number of breast cancer patients is increasing, which means that the incidence of cancer is increasing.

\section{CONCLUSTON}

It needs to be taken advantage of the facts that earlyonset breast cancer is very effective in curing and in this regard work plans should be directed to: health education of the population, education of women for proper and regular breast self-examination, education for regular screening for both women and the general practitioners who should support and educate the population on regular screening exams, as well as programs designed to support women who are being treated for breast cancer. This would reduce the frightening numbers of breast cancer deaths in the 21st century, the age of technology and the very advanced imaging devices in medicine. 